\title{
Assessment of Seed Maize Systems and Potential Demand for Climate-Smart Hybrid Maize Seed in Africa
}

\author{
George Marechera ${ }^{1}$, Grace Muinga ${ }^{1} \&$ Patrick Irungu ${ }^{2}$ \\ ${ }^{1}$ African Agricultural Technology Foundation (AATF), Nairobi, Kenya \\ ${ }^{2}$ University of Nairobi, Nairobi, Kenya \\ Correspondence: George Marechera, African Agricultural Technology Foundation, P.O. Box 30709-00100, \\ Nairobi, Kenya. Tel: 254-734-992-224. Email: g.marechera@aatf-africa.org
}

Received: May 19, 2016

doi:10.5539/jas.v8n8p171

\author{
Accepted: July 1, $2016 \quad$ Online Published: July 15, 2016 \\ URL: http://dx.doi.org/10.5539/jas.v8n8p171
}

\begin{abstract}
Africa lacks a steady supply of good quality seed due in part to lack of timely development and conveyance of seed technologies to farmers. This study evaluated the performance of national seed systems of five countries in eastern and southern Africa where a consortium of public-private organizations are implementing the Water Efficient Maize for Africa (WEMA) project. WEMA aimed at developing and deploying drought-tolerant and insect-pest-protected maize hybrids (climate-smart hybrids) to smallholder farmers royalty-free. The objectives of the study were to assess the main components of the seed maize systems, their institutional frameworks, and estimate the potential demand for WEMA climate-smart hybrid maize seed to guide in upscaling the seed technology to other African countries. Primary data was gathered from key experts in the seed maize value-chain of each country. Secondary data came from national statistics bureaux to estimate the potential demand for WEMA seed maize. Results showed that farmers in all five countries except South Africa overwhelming rely on the informal seed system. The formal seed system is over-regulated creating unnecessary delays in the release and commercialization of improved seed varieties. It also increases the cost of developing new seed technology. Except South Africa, the demand for seed maize in the other four WEMA countries will grow by $4.1 \%$ annually from 31,614 to 35,863 metric tons of certified seed over 2014-2020 period. The study advances several recommendations to improve the efficiency of the seed maize systems, which when implemented, will undoubtedly improve food security in Africa.
\end{abstract}

Keywords: African seed-system, Climate-smart maize hybrids, Seed regulatory-framework, Potential seed-demand, WEMA public-private-partnership, DroughtTEGO ${ }^{\mathrm{TM}}$

\section{Introduction}

Maize (Zea mais) is the leading food staple in sub-Saharan Africa (SSA) whose consumption is second only to cassava. The crop plays a key role in food security, income generation and poverty alleviation among the millions of African farmers engaged in its production, value addition and marketing ("Maize crop-IITA", n.d.). However, one of the main challenges to maize production in SSA is lack of good quality seed. This has constrained efforts to increase maize yields thereby consigning millions of Africans to hunger, food insecurity and poverty. Availability of good quality seed is important for increasing crop production and productivity particularly given declining soil fertility and shortage of arable land due to high and growing population (Tripp \& Rohrbach, 2001).

Following the adoption of neo-liberal economic reforms in Africa in the early 1990s, the seed maize sector in most SSA countries has undergone significant changes (Nambiro, De Groote, \& Kosura, 2001). These reforms reduced the dominant role hitherto played by the public sector in the production and distribution of hybrid seed and allowed more private sector participation in the seed value chain. However, in some SSA countries, and for varied reasons, the private sector has not adequately taken up the role left by the State. Therefore, although private companies exist for marketing improved seed, the majority of farmers in SSA still use traditional and unimproved low-yielding seed varieties (Langyintuo et al., 2010; Joughin, 2014). Accordingly, efforts geared towards increasing food production in SSA are likely to fail given the differing levels of private sector participation in the seed sector in the continent. 
Literature on the performance of the African seed systems and their institutional framework is thin and widely scattered in websites and in grey literature. For instance, apart from (Nambiro et al., 2001; Ayieko \& Tschirley, 2006; Langyintuo et al., 2010; Keyser, 2013; Joughin, 2014), there is no comprehensive and systematic information on seed maize systems in Africa. The information gap is glaring even for the five countries in the eastern and southern Africa-Kenya, Mozambique, South Africa, Tanzania and Uganda-where a consortium of public-private partnership organizations have been implementing the Water Efficient Maize for Africa (WEMA) project since 2008. The project aims to develop and deploy drought-tolerant and insect-pest protected maize hybrids (climate-smart hybrids) royalty-free to smallholder farmers in Africa (Oikeh et al., 2014). As such, policy makers, researchers and other stakeholders lack evidence-based information that would aid in policy design and programming at national and continental levels. This study was therefore designed to address this knowledge gap. The objectives of the study were to (i) assess the main components of the seed maize systems in the five WEMA countries, (ii) document the institutional framework anchoring seed maize systems in those countries, and (iii) estimate the potential demand for climate-smart seed maize in the five countries. The information generated by this study will be useful in guiding policy design and promotion efforts needed to upscale the uptake of WEMA climate-smart hybrids in the rest of Africa.

\section{Methodology}

This study used the qualitative research design. According to (Taylor \& Bogdan, 1998), a qualitative design enables the researcher to appreciate and capture the in-depth nature of a phenomenon or behaviour at hand. In this study, primary data was collected from key experts in the seed maize value chain in the five countries. Key questions revolved around: a) a description of the main components of the seed maize system in each country, b) identification of key players in the seed maize system including their roles and challenges, and c) documentation of institutional arrangements that guide the seed system of each country. Secondary data were obtained from the seed regulatory authorities in each country.

The data were used to estimate the potential demand for seed maize in each country up to 2020 . The following demand function based on (Working, 1943) was used:

$$
\text { Potential demand }=Q_{0}\left(1+P_{r}\right)^{n}\left(1+Y_{r} \times E_{y}\right)^{n}
$$

Where,

$Q_{0}=$ Maize demand [i.e., total population multiplied by per capita maize consumption in $\mathrm{kg} /$ capita at base year (2011)]; $P_{r}=$ Population growth rate; $Y_{r}=$ Annual rate of per capita growth; $E_{y}=$ Income elasticity of maize demand; $n=$ number of years.

A summary of parameters used to estimate the potential demand for seed maize in WEMA countries from 2014 to 2020 was made (Table 1). The population growth rates were derived from The World Bank, while data for annual per capita maize consumption and initial maize demand were obtained from the Food and Agricultural Organization's (FAO) Food Balance datasheets (FAO). Data on expenditure share on maize, income elasticity of maize demand and adoption of improved maize varieties (IMV) were obtained from literature within those countries, e.g., Van Zyl (1986) for South Africa. The population in arid and semi-arid lands (ASALs) was derived from the national population statistics for each country, for example, National Bureau of Statistics (2012) for Tanzania and National Council for Population and Development (NCPD) (2013) for Kenya.

Table1. Summary of parameters used to estimate potential demand for seed maize in five WEMA countries

\begin{tabular}{|c|c|c|c|c|c|c|}
\hline Country & $\begin{array}{l}\begin{array}{l}\text { Population } \\
\text { growth rate, } \mathrm{Pr} \\
(2005-2011, \%)\end{array}\end{array}$ & $\begin{array}{l}\text { Annual growth rate } \\
\text { of per capita maize } \\
\text { consumption, } \operatorname{Yr}(\%)\end{array}$ & $\begin{array}{l}\text { Maize demand } \\
{\left[\mathrm{Q}_{0}\right] \text { in } 2011} \\
(\mathrm{MT})\end{array}$ & $\begin{array}{l}\text { Expenditure } \\
\text { share of } \\
\text { maize }(\%)\end{array}$ & $\begin{array}{l}\text { Income } \\
\text { elasticity, } \\
\text { Ey }\end{array}$ & $\begin{array}{l}\text { Adoption } \\
\text { rates of } \\
\text { IMVs (\%) }\end{array}$ \\
\hline Kenya & 2.7 & -1.1 & $3,240,359$ & 0.150 & 0.90 & 45 \\
\hline Mozambique & 2.7 & 1.6 & $1,430,614$ & 0.134 & 1.31 & 15 \\
\hline South Africa & 1.2 & -1.2 & $5,210,485$ & 0.060 & 1.39 & 72 \\
\hline Tanzania & 3.0 & -0.4 & $2,646,871$ & 0.180 & 0.99 & 45 \\
\hline Uganda & 3.4 & 6.8 & $1,430,524$ & 0.095 & 0.53 & 43 \\
\hline
\end{tabular}

Note. IMV: Improved Maize Varieties; ASAL: Arid and semi-arid lands.

Source: Authors' computations. 


\section{Results and Discussion}

Maredia et al. (1999) define a seed system as organizations, individuals and institutions involved in different seed system functions, i.e., the development, multiplication, processing, storage, distribution and marketing of seeds. It includes both informal and formal sectors. The informal sector comprises of individual farm households, each carrying out most of the seed system functions on their own with little or no specialization for own use and for exchange with a limited number of other farmers. The formal sector is made up of public and private organizations with specialized roles in supplying seed of new and improved maize varieties (Keyser, 2013; ASARECA/KIT, 2014). The performance of a crop improvement programme in any country will depend largely on the effectiveness of its seed delivery system. The following section reports in detail the attributes of the seed systems in the five WEMA countries.

\subsection{Seed Maize Systems in WEMA Countries}

\subsubsection{The Kenya Seed System}

Kenya has one of the most developed seed systems in Africa with over 70 registered seed merchants. Most of these merchants are members of the Africa Seed Traders' Association (AFSTA) and Seed Trade Association of Kenya (STAK). Despite its development, the formal seed sector in Kenya accounts for only $25 \%$ of the country's seed needs. The remainder comes from the informal seed system, mainly from farmers' saved seed. The Kenya seed system has main component including the main value chain actors (Table 2).

The main actors in the seed value chain in Kenya include the Kenya Plant Health Inspectorate Service (KEPHIS) that offers phytosanitary and seed certification services, Kenya Agricultural and Livestock Research Organization (KALRO) and national universities, that mainly conducts variety development and testing, seed companies including Kenya Seed Company (KSC), who produce certified seed, and agro-dealers who retail seed (Table 2). KSC controls about $80 \%$ of total annual seed production and sales. The seed industry in Kenya is highly regulated and variety release process is rigorously controlled. Variety testing, approval and release can take several years.

Table 2. Main components of the formal maize seed system value chain in Kenya

\begin{tabular}{lll}
\hline Value chain component & Key stewardship issues & Main value chain actors \\
\hline Variety development/ improvement & $\begin{array}{l}\text { Seed company, farmers, and consumer } \\
\text { customer requirements }\end{array}$ & $\begin{array}{l}\text { KALRO, Universities, CIMMYT, KSC, } \\
\text { other seed companies }\end{array}$ \\
Variety approval, registration \& regulation & $\begin{array}{l}\text { Intellectual property and variety } \\
\text { performance }\end{array}$ & KEPHIS \\
Breeders \& Foundation Seed Production & Variety release procedures & KALRO, Universities, KSC, other seed \\
Certified seed production & $\begin{array}{l}\text { Contracts growers for certified seed, seed } \\
\text { production procedures }\end{array}$ & $\begin{array}{l}\text { KSC, other seed companies, community } \\
\text { organisations }\end{array}$ \\
Seed processing and packaging & $\begin{array}{l}\text { Processing procedures, packaging \& quality } \\
\text { assurance }\end{array}$ & KSC, seed companies \\
Variety promotion and Marketing & Advertising, labelling information & Distribution, pricing, extension information, \\
Seed distribution and Sales & Customer support & SMEs, seed merchants, agro-dealers \\
& & \\
\hline
\end{tabular}

Source: Survey data.

\subsubsection{Mozambican Seed System}

The main seed value chain actors in Mozambique include the Instituto de Investigação Agrária de Moçambique (IIAM-Institute of Agricultural Research) under the Mozambique National Directorate of Agrarian Services (DNSA) that regulates variety development, and the Seed Unit of Mozambique (SNS) that controls variety approval and registration. Others include seed merchants and companies that package and distribute certified seed to farmers (Table 3). It is noteworthy that plant breeding in Mozambique is not as developed as in the other WEMA countries. Thus, the IIAM is the sole player in maize breeding work. Sementes de Moçambique Ltda (SEMOC), Seed Co and Pannar are the major companies involved in commercial seed production in Mozambique. 
The main players in seed processing and packaging are SEMOC, Pannar and SeedCo. These companies are also involved in seed promotion and marketing along with government extension staff. The main challenges in the Mozambican seed system include inadequate seed breeders and basic seed, low seed demand, unavailability, high seed cost, and inaccessibility of certified seed. Low seed access is due to the fact most seed stores are located in cities and towns away from the main maize production areas.

Table 3. Main components of formal maize seed system in Mozambique

\begin{tabular}{|c|c|c|}
\hline Value chain component & Key stewardship issues & Value chain actors \\
\hline Variety development/improvement & $\begin{array}{l}\text { Seed company, farmers, and consumer customer } \\
\text { requirements }\end{array}$ & IIAM \\
\hline Variety approval, registration \& regulation & Intellectual property and variety performance & SNS \\
\hline Breeders \& Foundation Seed Production & Variety release procedures & IIAM-USEBA \\
\hline Certified seed production & $\begin{array}{l}\text { Contracts growers for certified seed, seed } \\
\text { production procedures }\end{array}$ & SEMOC, Pannar \\
\hline Seed processing and packaging & $\begin{array}{l}\text { Processing procedures, packaging \& quality } \\
\text { assurance }\end{array}$ & SEMOC, Pannar, Seed-Co \\
\hline Variety promotion and Marketing & Advertising, labelling information & $\begin{array}{l}\text { SEMOC, Pannar, Seed-Co, SMEs, } \\
\text { Government Extension }\end{array}$ \\
\hline Seed distribution and Sales & $\begin{array}{l}\text { Distribution, pricing, extension information, } \\
\text { Customer support }\end{array}$ & Seed merchants, Agro-dealers \\
\hline
\end{tabular}

Source: Survey data.

\subsubsection{South African Seed System}

South Africa has the most-developed formal seed system in Africa. However, this does not mean it is best suited to provide smallholder resource-poor farmers with appropriate and affordable seed. The formal seed system was worth R3.6 billion in 2010. Maize accounts for 59\% of the total seed market value in South Africa. The South African seed system has a dual character in tandem with the existing agricultural system that consists of large-scale commercial and small-scale resource-poor sectors. The large-scale sector is characterized by intensive use of hybrid and genetically modified (GM) seed, separation of seed ownership from agricultural production, use of complementary inputs such as mineral fertilizers, pesticides and commercial marketing institutions (Gouse, 2012; Abidoye \& Mabaya, 2014). Smallholder farmers in South Africa plant maize on roughly 0.5 to 1 hectare (Gouse, 2012). Before the introduction of GM maize in smallholder farming system by Monsanto in 2002/2003 season, most farmers used saved seed. By 2007/2008 season, only 23\% of smallholder farmers that regularly buy hybrid seed from the three largest maize seed companies had adopted GM seed (Gouse, 2012). As such, the South African formal seed system mainly focuses on commercial farmers. One of the major weaknesses of the South African seed system is its concentration on large-scale commercial farmers. Little attention is paid to the smallholder farming system; for example, by making seed available in small packages.

The formal seed system in South Africa produces white maize varieties for human consumption and yellow maize varieties for animal feed. Many of these varieties rely on a narrow germplasm base and there are small differences between one variety and another. The main actors in the South African seed system are detailed in Table 4 below. The main challenges in the South African seed system include inadequate seed varieties suitable for marginal areas where most smallholder farmers live, high seed cost and inappropriate package sizes for smallholder farmers. 
Table 4. Main components of formal seed system value chain in South Africa

\begin{tabular}{|c|c|c|}
\hline Value chain component & Key stewardship issues & Value chain actors \\
\hline Variety development/improvement & $\begin{array}{l}\text { Seed company, farmers, and consumer } \\
\text { customer requirements }\end{array}$ & $\begin{array}{l}\text { ARC, Monsanto, Pioneer, Pannar, Klein } \\
\text { Karoo, MNCs }\end{array}$ \\
\hline $\begin{array}{l}\text { Variety approval, registration \& } \\
\text { regulation }\end{array}$ & Intellectual property and variety performance & \multirow{2}{*}{$\begin{array}{l}\text { Registrar of Varieties-SANSOR, ARC, } \\
\text { Monsanto, Pioneer, Pannar, Klein Karoo, } \\
\text { MNCs }\end{array}$} \\
\hline Breeders \& Foundation Seed Production & Variety release procedures & \\
\hline Certified seed production & $\begin{array}{l}\text { Contracts growers for certified seed, seed } \\
\text { production procedures }\end{array}$ & $\begin{array}{l}\text { Monsanto, Pioneer, Pannar, Klein Karoo, } \\
\text { Large-scale farmers }\end{array}$ \\
\hline Seed processing and packaging & $\begin{array}{l}\text { Processing procedures, packaging \& quality } \\
\text { assurance }\end{array}$ & $\begin{array}{l}\text { Monsanto, Pioneer, Pannar, Klein Karoo, } \\
\text { Large-scale farmers }\end{array}$ \\
\hline Variety promotion and Marketing & Advertising, labelling information & $\begin{array}{l}\text { Monsanto, Pioneer, Pannar, Klein Karoo, } \\
\text { Large-scale farmers }\end{array}$ \\
\hline Seed distribution and Sales & $\begin{array}{l}\text { Distribution, pricing, extension information, } \\
\text { Customer support }\end{array}$ & $\begin{array}{l}\text { Advance seed, Sakata Seed, Monsanto, } \\
\text { Pioneer, Pannar, Klein Karoo, Large-scale } \\
\text { farmers }\end{array}$ \\
\hline
\end{tabular}

Source: Survey data.

\subsubsection{Tanzanian Seed System}

The Tanzanian seed system is dominated by the informal seed system in which farmers use seed saved from previous seasons. The formal system accounts for $25 \%$ of the national seed requirement (USAID, 2013). In 2012, there were only 27 registered seed companies in Tanzania, which are members of the Tanzania Seed Trade Association (TASTA), and less than 2000 registered agro-dealers (USAID), 2013). The Agricultural Seed Agency (ASA), a government institution, has the mandate of producing quality seeds for farmers. It mainly produces and supplies maize open pollinated varieties (OPV) mainly targeting mid-altitude and highland agro-ecologies. The Tanzania Official Seed Certification Institute (TOSCI) is responsible for field and seed inspection; sampling; seed testing; variety evaluation and verification through National Performance Trials (NPT); Distinctness, Uniformity and Stability (DUS) observations and control plot testing. TOSCI thus certifies seed varieties. TOSCI has recently introduced white labels costing TSh 300 (USD 0.14) each to reduce the frequency of fake seeds. Other seed value chain actors include national universities including Sokoine, Agricultural Research Institute (ARI) and government farms where variety trials are conducted (Table 5). The main challenges facing the Tanzanian seed system include inadequate certified seed production primarily due to low funding of seed production programs, weak regulatory framework, crowding out of private sector by the public sector, and high cost and lengthy time needed to register seed varieties.

Table 5. Main components of formal seed system value chain in Tanzania

\begin{tabular}{|c|c|c|}
\hline Value chain component & Key stewardship issues & Value chain actors \\
\hline Variety development/improvement & $\begin{array}{l}\text { Seed company, farmers, and consumer } \\
\text { customer requirements }\end{array}$ & ARI, Sokoine University, Seed companies \\
\hline Variety approval, registration \& regulation & Intellectual property and variety performance & TOSCI \\
\hline Breeders \& Foundation Seed Production & Variety release procedures & $\begin{array}{l}\text { Government Seed Farms, ASA, ARI, Seed } \\
\text { companies }\end{array}$ \\
\hline Certified seed production & $\begin{array}{l}\text { Contracts growers for certified seed, seed } \\
\text { production procedures }\end{array}$ & $\begin{array}{l}\text { Contract growers, SMEs, Government } \\
\text { Seed Farms }\end{array}$ \\
\hline Seed processing and packaging & $\begin{array}{l}\text { Processing procedures, packaging \& quality } \\
\text { assurance }\end{array}$ & Government Seed Farms, SMEs \\
\hline Variety promotion and Marketing & Advertising, labelling information & Seed companies, SMEs \\
\hline Seed distribution and Sales & $\begin{array}{l}\text { Distribution, pricing, extension information, } \\
\text { Customer support }\end{array}$ & MNCs, SMEs, Agro-dealers \\
\hline
\end{tabular}

Source: Survey data. 


\subsubsection{Ugandan Seed System}

The formal seed sector in Uganda accounts for only $10 \%$ of the total national seed demand. There are more than 35 registered seed companies involved in growing, processing, and marketing of maize seed in Uganda. These companies also sell other agro-inputs including fertilizers, chemicals and farm equipment. The Uganda Seed Trade Association (USTA) is the umbrella body that governs seed companies. Uganda imports some seed from Kenya, Zimbabwe and Zambia. Some seed companies in Kenya also operate in Uganda to take advantage of its favourable rainfall.

Most small-scale farmers in Uganda use saved seed, which reduces the demand for certified seed resulting in low yields. As in Tanzania, the Ugandan seed system is threatened by the presence of fake seed. Accordingly, USTA has introduced a unique label or code that is inserted in certified maize seed packs for identification by farmers. Although this effort is in place, seed companies have had to revise their seed prices upwards to cater for this additional cost. In the long term, this measure may deter farmers from purchasing improved seed due to the added cost.

Seed certification in Uganda is conducted by the National Seed Certification Service (NSCS), a regulatory unit in the Ministry of Agriculture, Animal Industry and Fisheries (MAAIF). The NSCS relies on descriptors provided by seed breeders to ascertain the variety. Apart from the NSCS, the other key players in the seed certification process are the National Agricultural Research Organization (NARO), national universities and multinational companies (Table 6). The wide array of agro-ecologies in Uganda presents challenges for the development of seed varieties. Other challenges include inadequate maize breeders, low funding, poor infrastructure and supporting facilities, and weak seed distribution system with high transaction costs.

Table 6. Main components of formal seed system value chain in Uganda

\begin{tabular}{lll}
\hline Value chain component & Key stewardship issues & Value chain actors \\
\hline Variety development/improvement & $\begin{array}{l}\text { Seed company, farmers, and consumer customer } \\
\text { requirements }\end{array}$ & NARO, Makerere University \\
Variety approval, registration \& regulation & Intellectual property and variety performance & NSCS \\
Breeders \& Foundation Seed Production & Variety release procedures & NARO-Breeder, SMEs-Foundation \\
Certified seed production & $\begin{array}{l}\text { Contracts growers for certified seed, seed } \\
\text { production procedures }\end{array}$ & SMEs, NGOs, CBOs, MNCs \\
Seed processing and packaging & $\begin{array}{l}\text { Processing procedures, packaging \& quality } \\
\text { assurance }\end{array}$ & SMEs, MNCs \\
Variety promotion and Marketing & Advertising, labelling information & SMEs, MNCs \\
Seed distribution and Sales & Distribution, pricing, extension information, & Wholesalers, Seed merchants, \\
& Customer support & Agro-dealers \\
\hline
\end{tabular}

Source: Survey data.

\subsection{Maize Varieties Released in WEMA Countries (1964-2014)}

In the last 50 years, Kenya has released only 240 maize varieties of which $10 \%$ are WEMA climate-smart hybrids released in the last three years (Table 7). However, among the five WEMA countries, Kenya is second only to South Africa's 625 maize variety releases over the same period. With 625 maize varieties, South Africa had the highest number of variety releases accounting for $63.9 \%$ of all the maize varieties released in the five WEMA countries between 1964 and 2014 (see Table 7). South Africa has had the highest variety release rates of all the five WEMA countries followed by Kenya (Table 7). The private sector dominates the variety releases in South Africa, Kenya and Tanzania, indicating its strong presence in these countries. 
Table 7. Maize varieties released in WEMA countries (1964-2014)

\begin{tabular}{lllll}
\hline \multirow{2}{*}{ Country } & \multicolumn{4}{c}{ Number of maize varieties released } \\
\cline { 2 - 5 } & Total registered varieties & Proportion (\%) & Released in 2014 & Proportion (\%) \\
\hline Kenya & 240 & 24.5 & 10 & 22.7 \\
Mozambique & 19 & 1.9 & 4 & 9.1 \\
South Africa & 625 & 63.9 & 18 & 40.9 \\
Tanzania & 75 & 7.7 & 8 & 18.2 \\
Uganda & 19 & 1.9 & 4 & 9.2 \\
Total & $\mathbf{9 7 8}$ & $\mathbf{1 0 0}$ & $\mathbf{4 4}$ & $\mathbf{1 0 0}$ \\
\hline
\end{tabular}

Source: Survey data.

\subsection{Institutional Arrangements in Seed Systems in WEMA Countries}

Institutional arrangements refer to the regulatory system governing the seed system of each country. Kenya and South Africa have plant breeders rights (PBRs) and are members of the International Seed Testing Association (ISTA) and Organization for Economic Cooperation and Development (OECD) Seed Scheme. Thus, their breeders have exclusive legal rights to develop, commercialize, distribute and receive royalties from new seed varieties. Although Tanzania and Mozambique have PBRs, they are not members of ISTA or OECD Seed Scheme. Tanzania has however applied for membership in OECD seed scheme. In June 2014, Uganda signed the Plant Variety Protection Bill into law. Uganda is a member of ISTA but does not have accreditation; therefore, if the Orange certificate is needed for export, it relies on KEPHIS to provide the same. Uganda is also a member of the OECD seed scheme. Membership in either ISTA or OECD Seed Scheme is required for a country to qualify as an exporter of seeds. This implies that only Kenya and South Africa qualify as seed exporters among the five WEMA countries.

Except South Africa, seed testing and release procedures are still a preserve of the public sector in the other four WEMA countries. In South Africa, such procedures are under private organizations (Keyser, 2013). In both instances, traded seed must meet the sanitary and phytosanitary requirements of International Plant Protection Convention (IPPC). According to Setimela et al. (2009), a typical seed testing procedure involves a series of "value for cultivation and use" (VCU) and "distinctiveness, uniformity, and stability" (DUS) tests undertaken mainly by the national seed authority. Laboratory analysis is also required particularly if the seed is to be traded internationally (Keyser, 2013). While these series of tests are important in assuring the quality of traded seed, they often lead to delays in variety releases and escalate the cost of seed. This reduces the competitiveness of the seed system. For example, all the five WEMA countries except Mozambique charge between US\$200 and US\$600 per entry in DUS testing (Table 8). Seed breeders wishing to register their varieties for commercialization consider these costs too high. The costs are eventually passed on to the end-users thereby limiting seed access by resource-poor farmers in eastern and southern Africa.

Table 8. Distinctiveness, Uniformity, and Stability (DUS) requirements in WEMA countries

\begin{tabular}{lllllll}
\hline Country & $\begin{array}{l}\text { DUS } \\
\text { guidelines } \\
\text { published }\end{array}$ & $\begin{array}{l}\text { DUS } \\
\text { requirements } \\
\text { for OPV }\end{array}$ & $\begin{array}{l}\text { DUS } \\
\text { requirements } \\
\text { for hybrids }\end{array}$ & $\begin{array}{l}\text { No. of traits } \\
\text { measured } \\
\text { for DUS }\end{array}$ & $\begin{array}{l}\text { No. of } \\
\text { seasons for } \\
\text { DUS }\end{array}$ & $\begin{array}{l}\text { Fees paid } \\
\text { for DUS } \\
\text { (US\$) }\end{array}$ \\
\hline Kenya & Yes & Yes & Yes & 34 & 2 & 600 \\
Mozambique & No & Yes & Yes & Not specified & Not specified & Free \\
South Africa & Yes & Yes & Yes & 37 & 1 & 300 \\
Tanzania & Yes & Yes & Yes & 20 & 2 & 600 \\
Uganda & Yes & Yes & Yes & $>20$ & 2 & 200 \\
\hline
\end{tabular}

Source: Adapted from (Setimela et al., 2009).

Except Mozambique, all the other WEMA countries have published their DUS guidelines. In addition, all WEMA countries except South Africa require VCU data for variety registration. South Africa does not find conducting trials for DUS useful because the private sector is able to self-regulate. 
In Kenya, Uganda, Tanzania and Mozambique, where both DUS and VCU are a basic requirement for seed registration, the National Seed Authority (NSA) and the National Variety Release Committee (NVRC) determine if the varieties meet the DUS and VCU characteristics before they are released for commercialization. Mozambique's Seed Registration Unit does not have capacity to conduct DUS given that it started variety registration only in 2011. The DUS testing in the WEMA project in Mozambique started in 2015. A committee on seed release receives recommendations from the Seed Unit on varieties that qualify for release. The IIAM researchers in Maputo provide the technical backstopping on all seed release applications by conducting the necessary evaluation trials.

On average, Kenya has the longest time for seed release of 3.1 years while South Africa has the least (Table 9). In addition, it takes the longest time-two and a half years-for a released variety to become commercially available to farmers in South Africa. Unfortunately, delays in variety releases and commercialization have serious implications on seed availability and cost with a negative impact on agricultural productivity in WEMA countries.

Table 9. Time required for varietal release in WEMA countries

\begin{tabular}{llllll}
\hline \multirow{2}{*}{ Country } & \multicolumn{3}{c}{ Actual time to seed release (Years) } & & \multirow{2}{*}{$\begin{array}{l}\text { Time from release to when } \\
\text { available to farmers (Years) }\end{array}$} \\
\cline { 2 - 3 } Kenya & Mean & Min & Max & & Mean \\
Mozambique & 3.1 & 1.5 & 6 & 2.4 \\
South Africa & - & - & - & - \\
Tanzania & 2 & 2 & 2 & 2.5 \\
Uganda & 2.2 & 1 & 3 & 2 \\
\hline
\end{tabular}

Source: Adapted from Setimela et al. (2010).

One of the ways to address the problem of lengthy procedures for varietal and seed release could be to harmonize seed laws so that once a seed variety is released in one country it is regarded as released in all the others in the region. This will not only shorten the period for seed release but also enlarge the seed market through increased efficiency of the regulatory framework. The harmonized laws should require that countries accept trial data from other countries in the region for seed registration.

With 625 maize varieties, South Africa had the highest number of variety releases accounting for $63.9 \%$ of all the maize varieties released in the five WEMA countries between 1964 and 2014 (see Table 7). Of these, 51.2\% of the yellow maize varieties released in South Africa were GM, while among the white varieties, $38.4 \%$ were GM. This indicates that South Africa has widely embraced GM technologies in maize production, which could fairly explain its maize self-sufficiency and export surplus. Indeed, South Africa is the leading maize exporter in the continent (FAOSTAT, 2014).

Kenya is second to South Africa with 240 varieties in the last 50 years and 10 varieties in 2014 among the five WEMA countries. As of December 2014, 25 WEMA climate-smart hybrids were released in Kenya, six each in Uganda and Tanzania and two in South Africa (Table 7). In Kenya, the WE1101 hybrid sold under the brand name DroughtTEGO ${ }^{\mathrm{TM}}$, has been in cultivation by farmers in 39 sites since 2013 when it was first released. This variety has resulted in a $150 \%$ maize yield increase from a national average of 1.8 to 4.5 metric tons per hectare in the 13 early adopting communities in Kenya (AATF, 2014).

In South Africa, DroughtTEGO ${ }^{\text {TM }}$ was launched in December 2014. Initially, 10,000 seed packs of the WEMA climate-smart hybrid WE3127 were made available to smallholder famers during and immediately after the launch in South Africa. Three South African seed companies-Capstone Seeds, Jermart Seeds and Seed Co-were licensed to produce and distribute DroughtTEGO ${ }^{\mathrm{TM}}$ in 2015.

\subsection{Estimating Potential Demand for Climate-Smart Maize Seed in WEMA Countries}

The projected seed maize demand in the five WEMA countries between 2014 and 2020 were computed based on equation (1) (Table 10). Uganda, Mozambique and Tanzania were projected to experience high annual growth rates of seed maize demand at $7.1 \%, 4.8 \%$ and $2.6 \%$, respectively. Kenya will have a marginal growth rate of $1.7 \%$ while South Africa will experience a decline of $-0.5 \%$ per year. Despite the decline in seed maize demand in 
South Africa, the country will still have the highest demand among the five countries probably driven by its huge maize export demand, which creates an incentive to adopt improved technology. In all the other WEMA countries, the demand for seed maize will grow through to 2020 most probably driven by the insufficiency of domestic maize production.

Table 10. Demand (MT) for WEMA climate-smart hybrid basic/certified maize seed through to 2020

\begin{tabular}{llllllllll}
\hline Country & $\mathbf{2 0 1 4}$ & $\mathbf{2 0 1 5}$ & $\mathbf{2 0 1 6}$ & $\mathbf{2 0 1 7}$ & $\mathbf{2 0 1 8}$ & $\mathbf{2 0 1 9}$ & $\mathbf{2 0 2 0}$ & $\begin{array}{l}\text { Average Growth } \\
\text { rate (\%) }\end{array}$ & Average \\
\hline Kenya & 7,321 & 7,443 & 7,567 & 7,693 & 7,821 & 7,951 & 8,084 & 2 & $7,697.14$ \\
Mozambique & 3,332 & 3,492 & 3,660 & 3,836 & 4,020 & 4,214 & 4,416 & 5 & $3,852.86$ \\
South Africa & 11,523 & 11,468 & 11,413 & 11,358 & 11,303 & 11,249 & 11,195 & 0 & $11,358.43$ \\
Tanzania & 6,034 & 6,190 & 6,351 & 6,515 & 6,684 & 6,857 & 7,034 & 3 & $6,523.57$ \\
Uganda & 3,404 & 3,645 & 3,904 & 4,180 & 4,477 & 4,794 & 5,134 & 7 & $4,219.71$ \\
Total & $\mathbf{3 1 , 6 1 4}$ & $\mathbf{3 2 , 2 3 8}$ & $\mathbf{3 2 , 8 9 5}$ & $\mathbf{3 3 , 5 8 2}$ & $\mathbf{3 4 , 3 0 5}$ & $\mathbf{3 5 , 0 6 5}$ & $\mathbf{3 5 , 8 6 3}$ & 2 & $\mathbf{3 3 , 6 5 1 . 7 1}$ \\
\hline
\end{tabular}

Source: Authors.

\section{Policy Implications and Conclusion}

Maize is an important food staple in Africa and particularly in the WEMA countries. The proper functioning of the national seed maize system is critical not only for increasing farmer access to maize technologies but also to ensure the achievement of household and national food security. One of the reasons why Africa has not been able to feed itself is lack of access to quality seed (Keyser, 2013). As a result, the African farmer perpetually has to rely on saved seed leading to low yields, which exacerbates food insecurity. This study documented the components of national seed systems and their institutional frameworks in the five WEMA countries. It also estimated the projected demand for hybrid maize seed through to 2020 at 33,652 metric tons annually on average.

The results show that only South Africa and Kenya have well developed seed systems. The seed systems in the other three WEMA countries are still at infancy. In fact, the Mozambican seed system hardly exists although efforts have been put in place to do so. Except in South Africa, the formal seed system supplies only a small proportion of the total seed demand. Even in South Africa, resource-poor smallholder farmers, who constitute the bulk of the farming community, frequently rely on the informal seed system which is based on saved seed that is often genetically inferior, low yielding, and susceptible to diseases and pests. The lack of a proper functioning formal seed system undermines the goal of increased agricultural productivity which is expected to induce agriculture-led economic development in the Comprehensive Africa Agriculture Development Programme (CAADP) and re-echoed in the Malabo Declaration (Assembly/AU/Decl. 1(XXIII), 2014).

This study found that while the official regulation of the seed system is important to ensure quality seed, it often introduces serious time and monetary bottlenecks in the national seed systems in most WEMA countries. For example, while the seed variety release time averages 2.2 years in Tanzania and Uganda, it is 2.4 years in Kenya with a range of 2 to 6 years. Further, the time to the commercial availability of seed after variety release in WEMA countries is fairly long, ranging from 2 to 2.5 years on average. On the other hand, the cost of official seed testing ranges from US\$200 in Uganda to US\$600 in Kenya. Delays in variety release and commercialization has huge implications on seed availability, while the high cost constrains farmer seed access and reduces the competitiveness of the seed system. These issues could probably explain why most farmers in the WEMA countries, and indeed in most of Africa, use the informal seed system.

Despite the elaborate and expensive official seed testing process, most of the WEMA countries suffer from counterfeit seed. Although the data on the magnitude of this problem are lacking, anecdotal evidence suggests that about 30 to $40 \%$ of maize seed in WEMA countries is counterfeit (Joughin, 2014). While this problem could be attributed to unscrupulous behavior of seed merchants, evidence shows that it is fueled by inter alia weak and inadequate regulatory frameworks associated with dysfunctional and poorly funded institutions, undercapitalized seed companies and poor policy implementation. These inefficiencies result in low quality seed reaching the market, which discourages farmers' use of certified seed. In most cases, seed supply shortages not only make the seed unaffordable by resource-poor farmers but also create incentives for substandard seed quality and counterfeiting. In other cases, farmers are not even aware of the importance of using good quality seed. At the 
same time, stringent regulations and political patronage, as in the case of Uganda, discourage private sector competition (Joughin, 2014).

Given the rapidly growing human population in Africa generally and WEMA countries in particular, agricultural productivity growth will have to come from yield increases rather than expansion of cultivated area. This calls for intensification of agriculture based on cost-effective production and timely dissemination of improved seed. To achieve this goal, governments in WEMA countries should streamline their formal seed systems by paying particular attention to their regulatory frameworks and institutions, which this study found to be most constraining to the effective functioning of the seed system. In addition, there is need for more public and private sector investments in research and development of high quality seed that is adapted to local conditions. Governments could do well by handing over seed development, testing and dissemination to the private sector $a$ $l a$ in South Africa, European Union and North America. The private sector has the capacity to monitor compliance through self-regulation.

As provided for in the Malabo Declaration, there is need to introduce "smart incentives" to support the seed sector in terms of capitalizing the struggling seed companies, strengthening regulatory institutions, and availing farm credit to resource-poor farmers to enable them access to new seed technologies. It is only by doing these that the seed sector in Africa and WEMA countries in particular will be able to meet the increasing seed demand as found in this study.

\section{Acknowledgements}

The authors of this study gratefully acknowledge the funding and logistical support of the African Agricultural Technology Foundation (AATF) and its Water Efficient Maize for Africa (WEMA) Project partners during the study. Special appreciation to the reviewers; Dr Sylvester Oikeh, Dr Steven Mugo and Mr Mark Edge.

\section{References}

Abidoye, B. O., \& Mabaya, E. (2014). Adoption of genetically modified crops in South Africa: Effects on wholesale maize prices. Agrekon, 53(1), 104-123. http://dx.doi.org/10.1080/03031853.2014.887907

African Agricultural Technology Foundation (AATF). (2014). First Harvest of New Drought-Tolerant Seed Shows Strong Promise of Improved Maize Crops for Smallholder Farmers of Africa. AATF, Africa. Retrieved June 20, 2016, from http://www.aatf-africa.org/media-center/First-Harvest-of-New-DroughtTolerant-Seed-Shows-Strong-Promise

ASARECA/KIT. (2014). Tanzania Seed Sector Assessment: A Participatory National Seed Sector Assessment for the Development of an Integrated Seed Sector Development (ISSD) Programme in Tanzania. Retrieved from http://asareca.org/ asareca/sites/default/files/publications/Synthesis\%20Report\%20-Landscaping\%20 for\%20ISSD\%20Tanzania-Final.pdf

Assembly/AU/Decl. 1(XXIII). (2014). Malabo Declaration. Retrieved October, 2015, from http://caadp.net/sites/default/files/documents/sustaining-CAADP-momentum/Malabo_Declaration_on_Acc elerated_Agricultural_Growth_and_Transformation_for_Shared_Prosperity_and_Improved_Livelihoods_ad opted_June_2014-2.pdf

Ayieko, M., \& Tschirley, D. (2006). Enhancing access and utilization of improved seed for food security in Kenya. Tegemeo Institute of Agricultural Policy and Development, Egerton University, Kenya. Retrieved from http://fsg.afre.msu.edu/kenya/seed-presentation-final.pdf

FAOSTAT. (2014.). Retrieved June 20, 2016, from http://faostat3.fao.org/browse/Q/QC/E

Gouse, M. (2012). GM Maize as Subsistence Crop: The South African Smallholder Experience. Ag Bio Forum, 15(2), 163-174. Retrieved from https://www.researchgate.net/publication/282387065_GM_Maize_as Subsistence_Crop_The_South_African_Smallholder_Experience

Joughin, J. (2014). The Political Economy of Seed Reform in Uganda: Promoting a Regional Seed Trade Market.

Keyser, J. C. (2013). Opening up the markets for seed trade in Africa. Washington, DC: The World Bank. Retrieved from http://www-wds.worldbank.org/external/default/WDSContentServer/WDSP/IB/2013/10/28/ 000442464_20131028104148/Rendered/PDF/818340REVISED00o020379857B00PUBLIC0.pdf

Langyintuo, A. S., Mwangi, W., Diallo, A. O., MacRobert, J., Dixon, J., \& Bänziger, M. (2010). Challenges of the maize seed industry in eastern and southern Africa: A compelling case for private-public intervention to promote growth. Food Policy, 35(4), 323-331. http://dx.doi.org/10.1016/j.foodpol.2010.01.005 
Maize Crop-IITA. (n.d.). Retrieved June 15, 2016, from http://www.iita.org/maize

Maredia, M. K., Howard, J. A., Boughton, D., Naseem, A., Wanzala, M. N., \& Kajisa, K. (1999). Increasing Seed System Efficiency in Africa: Concepts, Strategies and Issues (Food Security International Development Working Paper No. 54578). Michigan State University, Department of Agricultural, Food, and Resource Economics. Retrieved from https://ideas.repec.org/p/ags/midiwp/54578.html

Nambiro, E., De Groote, H., \& Kosura, W. O. (2001). Market structure and conduct of the hybrid maize seed industry a case study of the Trans NZOIA district in western Kenya. Seven Eastern and Southern Africa Regional Maize Conference (pp. 474-479). Retrieved from https://www.researchgate.net/profile/Hugo_De Groote/publication/235733177_The_Hybrid_Maize_Seed_Industry_in_the_Transnzoia_District_of_Wester n_Kenya/links/5472cf410cf24bc8ea19a285.pdf

National Bureau of Statistics. (2012). National Sample Census of Agriculture 2007/2008 Small Holder Agriculture (No. Volume II: Crop Sector-National Report).

National Council for Population and Development (NCPD). (2013). Kenya Population Situation Analysis. Retrieved from http://kenya.unfpa.org/sites/esaro/files/pub-pdf/FINALPSAREPORT.pdf

Oikeh, S., Ngonyamo-Majee, D., Mugo, S. I. N., Mashingaidze, K., Cook, V., \& Stephens, M. (2014). The Water Efficient Maize for Africa Project as an Example of a Public-Private Partnership. In D. D. Songstad, J. L. Hatfield, \& D. T. Tomes (Eds.), Convergence of Food Security, Energy Security and Sustainable Agriculture (pp. 317-329). Springer Berlin Heidelberg. http://dx.doi.org/10.1007/978-3-642-55262-5_13

Setimela, P. S., Badu-Apraku, B., \& Mwangi, W. M. (2009). Variety testing and release approaches in DTMA project countries in sub-Saharan Africa. Harare, Zimbabwe: International Maize and Wheat Improvement Center.

Taylor, S. J., \& Bogdan, R. (1998). Introduction to qualitative research methods: A guidebook and resource (3rd ed.). New York: Wiley.

The World Bank. (n.d.). Retrieved June 17, 2016, from http://beta.data.worldbank.org

Tripp, R., \& Rohrbach, D. (2001). Policies for African seed enterprise development. Food Policy, 26(2), 147-161. http://dx.doi.org/10.1016/S0306-9192(00)00042-7

United States Agency for International Development (USAID). (2013). SeedCLIR Tanzania Pilot Report. Retrieved from http://www.eatproject.org/docs/tanzania_seedCLIR.pdf

Van Zyl, J. (1986). A Statistical Analysis of the Demand for Maize in South Africa. Agrekon, 25(3), 45-51. http://dx.doi.org/10.1080/03031853.1986.9524080

Working, H. (1943). Statistical Laws of Family Expenditure. Journal of the American Statistical Association, 38(221), 43. http://dx.doi.org/10.2307/2279311

\section{Copyrights}

Copyright for this article is retained by the author(s), with first publication rights granted to the journal.

This is an open-access article distributed under the terms and conditions of the Creative Commons Attribution license (http://creativecommons.org/licenses/by/4.0/). 